\title{
Does "Resetting” by Changing Corporate Name or Industry Category Appeal to Institutional Investments?
}

\author{
Paoyu Huang \\ Department of International Business, Soochow University \\ E-Mail: hpy@scu.edu.tw \\ Yensen Ni \\ Department of Management Sciences, Tamkang University \\ E-Mail: ysni@mail.tku.edu.tw \\ Yirung Cheng \\ Department of Management Sciences, Tamkang University \\ E-Mail: yirung@scsb.com.tw
}

\begin{abstract}
We investigate whether firms changing their names or industry categories once and more than once would affect institutional shareholdings. By utilizing 5,733 observations of the Taiwan Stock Exchange listed firms, we apply multiple regression models firstly and Petersen regression models for further investigation to enhance the robustness of the empirical results. We then disclose several important findings as follows. First, institutional investors might not prefer holding the shares of the firms changing their names more than once. We infer that the performances of the firms changing names more than once might be doubtful. Second, institutional investors might decrease the shareholdings of the firms with industry categories changed. We claim that institutional investors might suspect these firms probably existing corporate governance issues. Besides, we argue that, to our best understanding, this study might fill the gap in the existing literature due to that the issues, firms changing their names or industry categories once or more than once, seem rarely explored in the relevant studies.
\end{abstract}

Keywords: Corporate Name Change, Industry Category Change, Board Structure, Financial Ratio, Firm Value 


\section{INTRODUCTION}

Researchers have emphasized the importance of the role which institutional investors act in the business world for a long time. For example, Garg and Chawla (2015) argued that institutional investors are called the elephants, the movers, and the shakers of stock markets because of their money power. Stepanyan (2011) pointed out that foreign institutional investors have become significant players in the increasingly global financial markets. In addition, institutional investors are also of various significant functions. For instance, Ferreira and Matos (2008) found that foreign and independent institutions are involved in monitoring corporations worldwide. Tai, Lai, and Lin (2014) claimed that institutional investors are effective monitors of corporate risk management to enhance the probability and extent of hedging. Bajo et al. (2013) revealed that institutional investors play a central role in the bid process and can protect minority shareholders from being frozen out in the bid. Bushee (1998) declared that institutions are sophisticated investors who typically serve a monitoring role in reducing pressures for myopic behavior. Furthermore, foreign institutional investors own several features, including independence from local management, internationally diversified portfolios, and expertise in monitoring firms (Foster \& Warren, 2016; Luong et al., 2017).

Institutional investors manage considerable funds worldwide. Davis (2002) claimed that the proportions of equity held by institutional investors are rising across all OECD countries. While in the emerging markets, institutional investors contribute $30 \%$ of total market capitalization in India stock markets (Guha, 2018) as well as about $40 \%$ share outstanding held by foreign institutional investors in the Taiwan Stock Exchange (Ni, Liao, \& Huang, 2017). To sum up, in many countries, institutional investors have become dominant players in the financial markets (Gillan \& Starks, 2003; Lemma et al. 2018).

Aside from the investor aspect, we consider that corporate name might be another important factor for firm performance and find that names do matter for firms from the previous studies. For example, Horsky and Swyngedouw (1987) claimed that a company's name is commonly considered to be an integral part of its image, just like the quality of its products or the quality of its technical services. Furthermore, a firm's only asset is its name or reputation (Tadelis, 2003) and, once a firm is established, it is recognized by its name, which is uniquely associated with its characteristics and past performance (Tadelis, 1999). Muzellec (2006) argued that companies manage their corporate names more actively and treat them as corporate brands rather than merely trade names. Daly and Moloney (2004) pointed out that a brand is much more than simply a name or a logo. It represents value, promise, attitude, and feeling about brand and product. It is recognized as a major asset that the firm had established and invested 
over a prolonged period of years. Delattre (2002) argued that the name is the main component of any organization's identity. Chang and Young (2016) demonstrated that, compared with non-brand firms, brand firms performed better in and recovered quicker from the difficult economic times of the late 2000s. Glynn and Abzug (2002) revealed that organizational names encode central features of meaning (Olins, 1989) and organizational identity (Ashforth \& Gibbs, 1990; Watson et al. 2016).

In addition, although names may not capture the entirety of a firm's identity, to most of the people, corporations are "nothing but a name" (Boddewyn, 1967). Howe (1982) claimed that the company's name is one of its public images and a poor choice of name may be an obstacle for the firm to overcome, while a clever, such as amusing and informative, name may have a positive influence on individuals' perceptions of the company. Morris and Reyes (2011) argued that a well-chosen corporate name communicates much information and emotion to the firm's public. Green and Jame (2013) found that companies with short and easy to pronounce names have a higher breadth of ownership, greater share turnover, lower transaction price impacts, and higher valuation ratios.

Although some academic studies have analyzed the issue related to firm names changed, few studies have been explored the issue, whether institutional shareholdings would be affected by firm names changed, including once and more than once. Besides, to our best understanding, we argue that whether the firms changing industry categories, including once or more than once, might not be discussed in the existing literature. Moreover, we control the variables concerning fundamentals such as board structure and financial performance variables, which might derive the reason why firms are changing either firm names or industry categories. Thus, we argue that this study may contribute to our understanding of the firms changing either firm names or industry categories.

The firms which have changed their names or industry categories usually are suspected of the fundamental issues. However, we argue that the firms changing their names or industry categories might not result in the decrease of institutional shareholdings because some industries might have higher Price-to-Earnings (P/E) ratio, which might appeal to institutional investors to increase their shareholdings. Besides, we argue that the firms changing their firm names might change their fortune according to the wisdom of the oriental culture. Thus, we employ the Taiwan data due to the concern of oriental culture, and the revealed results might be different from the cognitions in terms of Western culture.

Whether there are differences between changing once (i.e. once only) and more than once (i.e. twice or above) for firm names and industry categories would be concerned in this study. We infer that the firms changing their names once might result 
from the attempt to enhance their businesses in each aspect. In consequence, the firm would be better off finally, which might encourage institutional investors to increase their shareholdings. On the contrary, when changing names more than once, institutional investors speculate that the firms might not generate benefits from the changes and result in the decrease in shareholdings for the firms accordingly. In reality, we argue that the inference aforementioned is rarely discussed in the relevant studies. Therefore, the above concern is the primary motivation for this study.

As a result, due to interested in the importance of corporate name for corporate performance, we explore whether changing firm names or industry categories once and even more than once would affect shareholdings of institutional investors. Besides, we take the variables related to corporate governance and financial performance into account as controlling variables since corporate governance and financial performance also tend to influence firm values. Therefore, we consider that the shareholding changes of institutional investors are likely affected by the variables related to corporate governance and financial statements.

Besides, we claim that the board often makes the decisions of enterprises. Thus, board structure variables, including directors' shareholding ratio, managers' shareholding ratio, directors' pledge ratio, CEO duality dummy, the board size, and electronic dummy, are concerned in this study. Moreover, financial variables, including net profit ratio, asset turnover ratio, and debt ratio, are taken into account in this study as well. Therefore, for more precise, we explore whether changing firm names or industry categories once and even more than once would affect the shareholdings of institutional investors after controlling these board structures and financial variables in this study.

We conduct a literature review and find that there are many studies related to the corporate name change, but few of them discuss the influence of the corporate name or industry category changed more than once. By employing the firms listed on the Taiwan Stock Exchange (TWSE) as our samples, we explore whether the changes of shareholdings for institutional investors would be affected by the firms changing their names or industry categories once and even more times.

In this study, we reveal several important findings as follows. First, institutional investors might not prefer holding the shares of firms with names changed more than once. We infer that, suspected by institutional investors, changing corporate name more than once probably because of the poor financial performance or the difficulty in operating business. Second, institutional investors might decrease the shareholdings of the firms with industry categories changed once and even more. We consider that it is due to the weak corporate governance for the TWSE listed firms. These findings, to our best understanding, are scantly reported in the past and are valuable for investors to 
make investment strategies. Third, we find that debt ratio and board size are negatively related to the shareholding change of institutional investors, which is consistent with that the firms with large board size or higher debt ratio might not have better corporate governance.

This study may contribute to the existing literature in several aspects. First, we pioneer to explore whether either firm names or industry categories changes would affect the shareholding changes of institutional investors, which seem to be hardly explored even unexplored in the relevant studies. Thus, the results of this study provide more valuable information for institutional investors in making investment decisions. Second, we examine the behaviors (i.e., the shareholding changes) of diverse institutional investors, including foreign institutional investors, domestic institutional investors, and security dealers in this study, which might be beneficial for investors due to being familiar with the decision making of diverse institutional investors in terms of either corporate name or industry category changed.

This paper is organized as follows. The literature review and hypotheses proposed are described in the second section. The third section introduces the data and methodology employed in this study. The fourth section presents the empirical findings and analysis. The conclusion is illustrated in the last section.

\section{LITERATURE REVIEW AND HYPOTHESES PROPOSED}

In this study, to familiarize ourselves with relevant studies, we conduct a survey of relevant literature related to institutional investors, corporate name or industry category change, corporate name or industry category change and financial markets, corporate governance, financial statements, and institutional investors, as well as the corporate name or industry category change and institutional investors.

\section{Institutional Investors}

Institutional investors are, in general, composed of foreign institutional investors, domestic institutional investors, as well as security dealers and act as the significant roles in the business world. For the relevant studies, Aggarwal et al. (2011) found that firms with higher institutional ownership are more likely to terminate poorly performing Chief Executive Officers (CEOs) and exhibit improvements in valuation over time, indicating that international portfolio invested by institutional investors promotes good corporate governance practices around the world. Bena et al. (2017) argued that greater foreign institutional ownership fosters long-term investment in tangible, intangible, as well as human capital and leads to significant increases in innovation output. Feng, Zhou, and Chan (2014) documented that institutional investors exhibit a smart money effect that can move new money into (out of) future good (poor) performers. Ferreira, 
Massa, and Matos (2009) found that foreign institutional investors, who built bridges between firms and reduce transaction costs as well as information asymmetry between bidder and target, act as the facilitators for corporate control in the international markets. In sum, the increased stability of institutional shareholdings is related to better firm performance (Hsu \& Wang, 2014) and share ownership by institutional investors, particularly for foreign financial institutions (Filatotchev, Lien, \& Piesse, 2005).

Furthermore, when the long-term institutional shareholdings, especially for foreign institutions, are higher, the firm performance is better. Huang and Shiu (2009) revealed a pronounced foreign ownership effect, whereby stocks with high foreign ownership outperform stocks with low foreign ownership. Khurana and Moser (2013) declared that institutions with long-term investment horizons are likely to discourage tax avoidance activities if such activities encourage managerial opportunism and reduce transparency. Luong et al. (2017) demonstrated that foreign institutional ownership has a positive, causal effect on firm innovation, indicating that foreign institutions act as the active monitors who provide insurance for firm managers against innovation failures and promote knowledge spillovers from high-innovation economies. Schuppli and Bohl (2010) argued that foreign institutions have a stabilizing effect on Chinese stock markets and contribute to market efficiency.

As for the investment strategy in terms of institutional investors, Grinblatt and Keloharju (2000) found that foreign investors tend to be momentum investors who are buying past winning stocks and selling past losers. Ko, Kim, and Cho (2007) discovered that foreigners and institutional investors tended to take a momentum strategy in response to the U.S. market returns, which seem to be information-driven of them in equity markets. Liu et al. (2014) revealed that, when making investment decisions, foreign funds tend to rely on some corporate governance indicators and have a preference for firms with a high percentage of state-owned shares.

In addition, Lai and Wang (2014) found that net trading volumes by foreign investors and investment trusts have the forecasting power for futures returns. Kaur and Dhillon (2010) concluded that the investment performance of Qualified Foreign Institutional Investors' (QFIIs') high holdings stocks is significantly better than that of QFIIs' low holdings stocks, which indicates that QFIIs' trading behavior has generated better returns and portfolio performance due to the full liberalization of stock markets.

Moreover, Zou, Tang, and Li (2016) revealed that both domestic funds and QFIIs tend to hold the shares of firms which are big, with relatively higher transaction costs, with better accounting performances, with higher Book-to-Market (B/M) ratios, or with a higher price to cash flow ratios. Dahlquist and Robertsson (2001) also demonstrated that foreigners show a preference for large firms, firms paying low dividends, and firms with large cash positions on their balance sheets. To sum up, all institutional investors 
have a strong preference for the stock of large firms and firms with good governance (Ferreira \& Matos, 2008).

\section{Corporate Name or Industry Category Change}

Due to the importance of a name for the firm, changing a firm's name is a major policy decision (Horsky \& Swyngedouw, 1987; Kashmiri \& Mahajan, 2015) and rebranding, that is changing firm's asset, should not be undertaken without careful planning (Daly \& Moloney, 2004). Delattre (2002) argued that each decision of corporate name modification has financial, marketing, and strategic effects. Green and Jame (2013) found that corporate name changes increase fluency on average, and fluency-improving name changes are associated with the increases in the breadth of ownership, liquidity, and firm value. Howe (1982) claimed that selecting new name is costly, implying that companies place positive values on the choices of "good" names, and investors may pay premiums for the securities of the companies with carefully selected names. Josev, Chan, and Faff (2004) found some evidence of a negative association between the corporate name change event and the abnormal return.

Morris and Reyes (2011) revealed that, despite the tremendous costs involved in corporate name changes, many corporations change names when pursuing a new strategic direction. Muzellec and Lambkin (2006) argued that the decision to rebrand is often provoked by structural changes, particularly for mergers and acquisitions, which have major effects on the corporation's identity and core strategy. Schmeltz and Kjeldsen (2016) found that, from a corporate branding perspective, the choice of a new name can be seen as a wish to stand out from a group of similar organizations. Conversely, from an institutional perspective, the name change can be perceived as a way to claim membership in a given organizational field. Wu (2010) pointed out that a firm adopts either a radically different name to disassociate from a poor reputation to a good one or a minor change by adding or deleting a part in its name that identifies it with a particular product to accompany a narrower or a broader business focus.

As for the effect of the corporate name change, Kot (2011) found that name changes have short-term stock price effects but no long-term relationship with stock price or operating performance. Bosch and Hirschey (1989) demonstrated a positive stock-price reaction to name change announcements by firms that have undergone major corporate restructuring recently. However, these effects are largely canceled in the post-announcement period. Thus, the valuation effects of name changes are only modest and transitory. Karbhari, Muhamad Sori, and Mohamad (2004) claimed that corporate name changes have no impact on shareholder wealth unless the news of approved corporate restructuring accompanies the announcement. Karpoff and Rankine (1994) found that the positive stock price reaction to the announcement of a name 
change is weak and sensitive to sample selection. In general, the corporate name changes may serve useful purposes which have small valuation effects or tend to be anticipated by investors. Rani and Asija (2017) revealed a positive and significant average abnormal return around the announcement date of name change. In addition, an increase in cumulative average abnormal return a few days before the announcement date has also been observed. However, the announcement of the new name change does not have positive signalling effects.

\section{Corporate Name or Industry Category Change and Financial Markets}

In general, the ultimate goal of corporate name change is to increase the financial performance of the firm. With the usage of the data reported by the Dow Jones News Service, Horsky and Swyngedouw (1987) reveal that the act of a name change serves as a signal which other measures to improve performance, such as changes in product offerings and organizational changes, will be seriously and successfully undertaken. Agnihotri and Bhattacharya (2017) find that investors in India respond positively to the announcement of firm name changes but this finding could not be used for predicting the long-term market performance of a firm with a name change. In contrast, in the developed markets, a name change might follow an improvement in long-term performance of the firm. Besides, Mathuva, Muthuma, and Kiweu (2016) point out that the positive impact of name change seems to be experienced about four years after the name change in Kenya. Yoon and Park (2015) disclose that firm name changes in Korea are negatively related with discretionary accruals, particularly when the firms change their names due to accumulated losses.

Aside from countries, firm name changes might also affect other markets and industries. For example, Lin, Yang, and Chang (2016) illustrate that investors in the U.S. markets react more positively towards firms experiencing oil-related name changes during the oil price surge. On the other hand, the effects of oil-related name changes appear to be transitory in the Canadian market. Furthermore, Carson, Cole, and Fier (2016) argue that corporate name changes have positive wealth effects for insurers and these effects are driven by the increased policy counts for those insurers that primarily sell to individual consumers.

Moreover, Cooper, Dimitrov, and Rau (2001) document a striking positive stock price reaction to corporate name changes to dotcom names. The "dotcom" effect produces cumulative abnormal return of 74 percent for 10 days surrounding the announcement day. Cooper et al. (2005) claim that, after the internet "crash" of mid2000, investors react positively to name changes for firms that remove dot.com from their name. This dot.com deletion effect produces cumulative abnormal return of $64 \%$ for 60 days surrounding the announcement day. 


\section{Corporate Governance, Financial Statements, and Institutional Investors}

As for investors' viewpoints, corporate governance would be regarded as an important index for investors. Das (2014) finds that firms with better corporate governance tend to be well-managed and have preeminent performance, which would increase the firms' values eventually and attract foreign investors. Chen et al. (2015) point out that interim CEOs are more likely to engage in earnings management to improve firm earnings performance than non-interim CEOs because the greater the income-increasing earnings management are, the more likely the interim CEOs are promoted. Li and Zaiats (2018) show that dual class firms are more likely to employ more shareholder rights provisions while exhibiting lower board and board committee independence than single class firms. Chung and Zhang (2011) argue that the fraction of shareholdings of institutional investors for a firm would improve the quality of the firm's governance structure. On the other hand, the proportion of institutions' shareholding for a firm would be affected by the firm's governance quality. Harford, Mansi, and Maxwell (2008) discover that, when distributing cash to shareholders, firms with weaker corporate governance structures actually have smaller cash reserves because of the repurchasing instead of increasing dividends to avoid future pay-out commitments.

Moreover, the ownership and board structure have critical impacts on firm value, which is supported by the literature. For instance, Abed, Al-Attar, and Suwaidan (2012) reveal that board size is the only variable significantly related to earnings management. Brick and Chidambaran (2010) find that variables, such as prior performance, firm characteristics, and governance characteristics, are important determinants of the board structure, indicating that well-functioned board structure has a positive impact on firm value. Min and Verhoeven (2013) show that firm value is increased by the monitoring activity of outsider's board. Upadhyay et al. (2017) argue that firms with a greater insider ratio could reduce firm risk and perform better when they operate in highly volatile environments. Barton and Simko (2002) report that share prices would be increased when the firms are able to exhibit the improvement of asset management.

In addition, financial performance is likely revealed by financial statements. $\mathrm{Ni}$, Liao, and Huang (2017) claim that corporate governance and financial performance are related to the shareholding change of foreign institutions. Besides, the financial risk of a firm may decline if the firm has a relatively high current ratio (Borokhovich et al., 2004).

\section{Corporate Name or Industry Category Change and Institutional Investors}


After reviewing the previous literature, studies directly relate to corporate name change and institutional investors are rarely explored. However, we presume that some other financial outcomes of firms can present their performances, which may be the main factor attracting institutional investors to invest. Thus, we explore the impact of corporate name change on the shareholding of institutional investors in this paper.

As mentioned in the literature review section for corporate name or industry category change, we find that most of the studies have similar conclusion, i.e., changing corporate name would not increase the firm's stock price in the long term (Bosch and Hirschey, 1989; Itzkowitz \& Itzkowitz, 2017; Karbhari, Muhamad Sori, and Mohamad, 2004; Karpoff and Rankine, 1994; Kot, 2011) and even have a negative association with abnormal returns of the firm (Josev, Chan, \& Faff, 2004). However, some researchers report the opposite results. For example, Lee (2001) reveals that announcements of “.com.” name changes are in relation to significant increases in stock prices and trading activity. Furthermore, the magnitude of investor reactions is significantly larger when name changes are accompanied by business strategies. Thus, we argue that these findings revealed might encourage institutional investors to increase the shareholding of the firms.

To our best understanding, the firms changing industry category is seldom explored and even is unexplored in the relevant studies. Even so, we endeavor to find few papers similar to this issue. For instance, Morris et al. (2001) investigate the reasons for the recent mergers in the retail finance category and find that the mergers have been explained by environmental changes adversely affecting membership and finances. Jacobides (2005) points out that the development of new intermediate markets breaks up the value chain and allows new types of vertically specialized firms to participate in an industry, which changes the competitive landscape of the industry. Thus, similar to environmental changes, we argue that the firms changing industry category might be somewhat like the corporate name changes (i.e., changing names with dot.com), which might affect the perception of investors and result in the changes of institutional investors' shareholdings. We then document that this might be an essential but unexplored issue in the relevant studies. Hence, we argue that this study might be able to fill up the gap of the existing literature.

Due to the shortage of relevant studies focusing on the effect of changing either corporate name or industry category on the shareholding of institutional investors, we then propose hypotheses shown below.

Hypothesis 1: Corporate name change would have a positive effect on the shareholding of institutional investors, including foreign institutions, domestic institutions, and security dealers, respectively. 
Hypothesis 2: Industry category change would have a positive effect on the shareholding of institutional investors, including foreign institutions, domestic institutions, and security dealers, respectively.

\section{DATA AND METHODOLOGY}

\section{Data}

We collect the data for the firms listed on Taiwan Stock Exchange (TWSE) from Taiwan Economic Journal (TEJ) over the data period 2009-2015 as our samples. Besides, in order to be familiar with the variables employed in this study, we define the variables as shown in Table 1.

Table 1 Definitions of Variables

\begin{tabular}{|c|c|}
\hline Variables & Definitions \\
\hline $\begin{array}{l}\text { Shareholding change of } \\
\text { foreign } \\
\text { institutions }\end{array}$ & $\begin{array}{l}\text { The shareholding ratio of foreign institutions at time } t \text { - The } \\
\text { shareholding ratio of foreign institutions at time } t-1\end{array}$ \\
\hline $\begin{array}{l}\text { Shareholding change of } \\
\text { domestic institutions }\end{array}$ & $\begin{array}{l}\text { The shareholding ratio of domestic institutions at time } t \text { - The } \\
\text { shareholding ratio of domestic institutions at time } t-1\end{array}$ \\
\hline $\begin{array}{l}\text { Shareholding change of } \\
\text { security dealers }\end{array}$ & $\begin{array}{l}\text { The shareholding ratio of security dealers at time } t \text { - The } \\
\text { shareholding ratio of security dealers at time } t-1\end{array}$ \\
\hline $\begin{array}{l}\text { Corporate name change } \\
\text { once dummy }\end{array}$ & Set to 1 if a firm changes its name once; otherwise, set to 0 \\
\hline $\begin{array}{l}\text { Corporate name change } \\
\text { more than once dummy }\end{array}$ & $\begin{array}{l}\text { Set to } 1 \text { if a firm changes its name more than once; otherwise, } \\
\text { set to } 0\end{array}$ \\
\hline $\begin{array}{l}\text { Industry category change } \\
\text { once dummy }\end{array}$ & $\begin{array}{l}\text { Set to } 1 \text { if a firm changes its industry category once; otherwise, } \\
\text { set to } 0\end{array}$ \\
\hline $\begin{array}{l}\text { Industry category change } \\
\text { more than once dummy }\end{array}$ & $\begin{array}{l}\text { Set to } 1 \text { if a firm changes its industry category more than once; } \\
\text { otherwise, set to } 0\end{array}$ \\
\hline Net profit ratio & Net profit over total sales \\
\hline Assets turnover ratio & Total sales over total assets \\
\hline Debt ratio & Total debts over total assets \\
\hline $\begin{array}{l}\text { Directors' shareholding } \\
\text { ratio }\end{array}$ & Total directors' shareholdings over total shares outstanding \\
\hline $\begin{array}{l}\text { Managers' shareholding } \\
\text { ratio }\end{array}$ & Total Managers’ shareholdings over total shares outstanding \\
\hline Directors’ pledge ratio & Directors’ pledged shares over total directors’ shareholdings \\
\hline CEO duality dummy & Set to 1 if the firms with CEO-Chair, otherwise, set to 0 . \\
\hline Board size & Total directors on the board \\
\hline Electronic dummy & Set to 1 for electronic firms; otherwise, set to 0 \\
\hline Firm scale & ln (market value) \\
\hline
\end{tabular}




\section{Model}

The model is set to determine whether the shareholding of institutional investors would be affected by the firms changing their firm names or industry categories after controlling board structure, financial statements, and other variables. The models employed in this study are shown below.

$\mathrm{Y}_{k, i, t}=\beta_{0}+\beta_{1} \mathrm{X} 1_{j, i, t}+\beta_{2} \mathrm{X} 2_{j, i, t}+\beta_{3}$ Net profit ratio ${ }_{i, t}+\beta_{4}$ Assets turnover ratio $_{i, t}+\beta_{5}$

Debt ratio $_{i, t}+\beta_{6}$ Directors' shareholding ratio $_{i, t}+\beta_{7}$ Managers' shareholding ratio $_{i, t}+\beta_{8}$ Directors' pledge ratio $_{i, t}+\beta_{9}$ CEO duality dummy ${ }_{i, t}+\beta_{10}$ Board size

${ }_{i, t}+\beta_{11}$ Electronic dummy $_{i, t}+\beta_{12}$ Firm scale $_{i, t}+\varepsilon_{i, t}, \mathrm{k}=1$ to 3

where $\mathrm{Y}_{1, i, t}$ is the shareholding change for foreign institutions as $\mathrm{k}=1$ for Model (1a) -

(4a), $Y_{2, i, t}$ is the shareholding change for domestic institutions as $\mathrm{k}=2$ for Model (1b) - (4b), and $Y_{3, i, t}$ is the shareholding change for security dealer as $k=3$ for Model (1c) - (4c), and

where $\mathrm{X} 1_{j, i, t}$ is corporate name change once dummy as $\mathrm{j}=1, \mathrm{X} 2_{j, i, t}$ is corporate name change more than once dummy as $\mathrm{j}=1$ for Regression model (1a) - (1c) and Pertersen model (3a) - (3c), X $1_{j, i, t}$ is industry category change once dummy as $\mathrm{j}=2$, and $\mathrm{X} 2_{j, i, t}$ is industry category change more than once dummy as $\mathrm{j}=2$ for Regession Model (2a) - (2c) and Petersen Model (4a) - (4c).

In the beginning, the variance inflation factor (VIF) tests are used to determine the existence of multicollinearity problems in these independent variables. The resulting VIF values for these variables are all less than two of these variables, indicating that multicollinearity issues are not serious in this study. Besides, due to the firm-year observations employed in this study, we argue that panel data models might be more appropriate than traditional multiple regression models. Afterward, owing to the defects of the panel data models proposed by Petersen (2009), we employ the model proposed by Petersen for grasping the relative accuracy after taking the structure of the data into account.

\section{EMPIRICAL FINDINGS AND ANALYSIS}

\section{Descriptive Statistics}

This study explores whether either corporate name or industry category change would affect the shareholding of institutional investors, including foreign institutions, domestic institutions, and security dealers. By utilizing 5,733 observations of the Taiwan Stock Exchange (TWSE) listed firms from Taiwan Economic Journal (TEJ) over the period 2009-2015 as our samples, Table 2 presents the descriptive statistics, including the number of observations, means, medians, standard deviations, minima, 
and maxima for the variables employed in this study.

Table 2 shows that the range between minima and maxima for the shareholding changes of diverse institutional investors is rather broad, and even these minima are 0 , indicating that the shareholding change of institutional investors is rather broad for the firms listed on the TWSE.

As for the financial statement variables, the average debt ratio is about $44 \%$, while the minimum and maximum values are $1.14 \%$ and $99.13 \%$, respectively. The results indicate that some TWSE listed firms might have corporate governance and financial issues due to higher financial leverages employed, which might affect the shareholding of institutional investors.

Regarding the board structure variables, we find that the average directors' holding ratio is about $22 \%$, but the minimum ratio is close to 0 . In addition, the maximum of directors pledge ratio is $100 \%$. Thus, we may deduce that some firms listed on the TWSE might have serious corporate governance issues resulting in the shareholding change of institutional investors as well.

Table 2 Descriptive Statistics

\begin{tabular}{|c|c|c|c|c|c|c|}
\hline Variables & Obs. & Mean & Median & Std. Dev. & Min. & Max. \\
\hline $\begin{array}{l}\text { Shareholding change of } \\
\text { foreign institutions }\end{array}$ & 5733 & 12.236 & 5.87 & 16.19 & 0 & 99.16 \\
\hline $\begin{array}{r}\text { Shareholding change of } \\
\text { domestic institutions }\end{array}$ & 5733 & 0.989 & 0.03 & 2.38 & 0 & 30.05 \\
\hline $\begin{array}{l}\text { Shareholding change of } \\
\text { security dealers }\end{array}$ & 5733 & 0.147 & 0 & 0.52 & 0 & 10.01 \\
\hline $\begin{array}{l}\text { Corporate name change } \\
\text { once dummy }\end{array}$ & 5733 & 0.212 & 0 & 0.41 & 0 & 1 \\
\hline $\begin{array}{l}\text { Corporate name change } \\
\text { more than once } \\
\text { dummy }\end{array}$ & 5733 & 0.037 & 0 & 0.19 & 0 & 1 \\
\hline $\begin{array}{l}\text { Industry category } \\
\text { change once dummy }\end{array}$ & 5733 & 0.172 & 1 & 0.50 & 0 & 1 \\
\hline $\begin{array}{l}\text { Industry category } \\
\text { change more than } \\
\text { once dummy }\end{array}$ & 5733 & 0.030 & 0 & 0.27 & 0 & 1 \\
\hline Net profit ratio & 5733 & 5.701 & 5.21 & 118.97 & $\begin{array}{c}- \\
3412.47\end{array}$ & 7458.61 \\
\hline Assets turnover ratio & 5733 & 0.881 & 0.77 & 0.63 & 0 & 6.62 \\
\hline Debt ratio & 5733 & 44.003 & 43.52 & 19.70 & 1.14 & 99.13 \\
\hline $\begin{array}{l}\text { Directors' shareholding } \\
\text { ratio }\end{array}$ & 5733 & 22.367 & 18.72 & 14.68 & 0 & 94.95 \\
\hline $\begin{array}{l}\text { Managers' } \\
\text { shareholding ratio }\end{array}$ & 5733 & 1.104 & 0.28 & 2.41 & 0 & 44.49 \\
\hline Directors' pledge ratio & 5733 & 9.278 & 0 & 17.48 & 0 & 100 \\
\hline CEO duality dummy & 5733 & 0.294 & 0 & 0.45 & 0 & 1 \\
\hline Board size & 5733 & 7.423 & 7 & 2.44 & 2 & 21 \\
\hline Electronic dummy & 5733 & 0.477 & 0 & 0.50 & 0 & 1 \\
\hline Firm scale & 5733 & 15.642 & 15.52 & 1.47 & 10.61 & 22.03 \\
\hline
\end{tabular}


Table 2 reports the means, medians, standard deviations, minima, and maxima of the dependent and independent variables. We explore whether the corporate name or industry category change would affect the shareholding of institutional investors after incorporating financial statements, board structure, and others as controlling variables. The financial statement variables include the net profit ratio defined as net profit over total sales, assets turnover ratio defined as total sales over total assets, and debt ratio defined as total debts over total assets. The board structure variables include directors' shareholding ratio defined as total directors' shareholdings over total shares outstanding, managers' shareholding ratio defined as total managers' shareholdings over total shares outstanding, and directors' pledge ratio defined as directors' pledged shares over total directors' shareholdings. CEO duality dummy is set to 1 if the firms with CEO-Chair, otherwise, set to 0 , board size defined as the total number of directors on the board, the electronic dummy is set to 1 for electronic firms; otherwise, set to 0 . The firm scale is measured as the logarithm of the market value.

\section{Multiple Regression Models}

In this study, we employ multiple regression models to explore whether the shareholding of institutional investors would be affected by either corporate name or industry category change after incorporating financial statements, board structure, and others as controlling variables ${ }^{1}$.

We explore whether the shareholding of institutional investors would be affected by a corporate name change, including changing once and more than once. The results are shown in Table 3 for the shareholding changes of foreign institutions, domestic institutions, and security dealers in Equations (1a) - (1c), respectively. We also employ financial statement variables, including net profit ratio, asset turnover ratio, and debt ratio, board structure variables, including directors' shareholding ratio, managers' shareholding ratio, directors' pledge ratio, CEO duality dummy, and board size, and others, including electronic dummy and firm scale, as the controlling variables. The tstatistics are based on the standard errors that are adjusted by heteroscedasticity (White, 1980) in Columns (1a) - (1c). Statistical significance values at the $10 \%, 5 \%$, and $1 \%$ levels are denoted by $*{ }^{* *}$, and ${ }^{* * *}$, respectively.

${ }^{1}$ We also concern whether the endogenous problem exists in our models since changing corporate name or industry category may affect institutional shareholdings and institutional shareholdings may affect changing corporate name or industry category. Thus, we use instrument variables which are estimated by both the two-stage least squares and generalized method of moments approaches and find that the variables related to corporate name or industry category change would be regarded as exogenous variables in our model as revealed insignificant Hausman statistics. 
Table 3 Results for Multiple Regression Models in Terms of the corporate Name Change

\begin{tabular}{|c|c|c|c|}
\hline Independent variable & $\begin{array}{l}\text { (1a) } \\
\text { Shareholding change } \\
\text { of foreign institutions }\end{array}$ & $\begin{array}{l}\text { ( } 1 \mathrm{~b}) \\
\text { Shareholding change } \\
\text { of domestic } \\
\text { institutions }\end{array}$ & $\begin{array}{c}\text { (1c) } \\
\text { Shareholding } \\
\text { change } \\
\text { of security dealers }\end{array}$ \\
\hline $\begin{array}{l}\text { Corporate name change once } \\
\text { dummy }\end{array}$ & $\begin{array}{l}-0.411 \\
(0.426)\end{array}$ & $\begin{array}{l}-0.096 \\
(0.075)\end{array}$ & $\begin{array}{c}0.106^{* * *} \\
(0.029)\end{array}$ \\
\hline $\begin{array}{l}\text { Corporate name change more } \\
\text { than once dummy }\end{array}$ & $\begin{array}{c}-1.954 * * \\
(0.865)\end{array}$ & $\begin{array}{l}-0.182 \\
(0.112)\end{array}$ & $\begin{array}{c}-0.154^{* * *} \\
(0.033)\end{array}$ \\
\hline Net profit ratio & $\begin{array}{c}0.001 \\
(0.001)\end{array}$ & $\begin{array}{c}0.000 \\
(0.000)\end{array}$ & $\begin{array}{c}0.000 \\
(0.000)\end{array}$ \\
\hline Assets turnover ratio & $\begin{array}{l}1.957 \\
(0.309)\end{array}$ & $\begin{array}{c}0.222 * * * \\
(0.043)\end{array}$ & $\begin{array}{c}0.001 \\
(0.009)\end{array}$ \\
\hline Debt ratio & $\begin{array}{c}-0.015 * * \\
(0.011)\end{array}$ & $\begin{array}{c}-0.009 * * * \\
(0.001)\end{array}$ & $\begin{array}{c}-0.001 * * \\
(0.001)\end{array}$ \\
\hline Directors' shareholding ratio & $\begin{array}{c}-0.027^{* *} \\
(0.019)\end{array}$ & $\begin{array}{c}-0.010^{* * *} \\
(0.002)\end{array}$ & $\begin{array}{c}-0.002 * * * \\
(0.001)\end{array}$ \\
\hline Managers' shareholding ratio & $\begin{array}{l}0.041^{*} \\
(0.079)\end{array}$ & $\begin{array}{l}-0.009 \\
(0.009)\end{array}$ & $\begin{array}{l}-0.003^{*} \\
(0.002)\end{array}$ \\
\hline Directors' pledge ratio & $\begin{array}{c}-0.031 * * * \\
(0.009)\end{array}$ & $\begin{array}{c}-0.003^{* *} \\
(0.002)\end{array}$ & $\begin{array}{l}0.002^{* *} \\
(0.001)\end{array}$ \\
\hline CEO duality dummy & $\begin{array}{c}1.631 * * * \\
(0.427)\end{array}$ & $\begin{array}{c}-0.143 * * \\
(0.068)\end{array}$ & $\begin{array}{l}-0.005 \\
(0.014)\end{array}$ \\
\hline Board size & $\begin{array}{l}-0.302 * * * \\
(0.076)\end{array}$ & $\begin{array}{c}-0.079 * * * \\
(0.011)\end{array}$ & $\begin{array}{c}-0.010^{* * *} \\
(0.002)\end{array}$ \\
\hline Electronic dummy & $\begin{array}{c}1.035^{* *} \\
(0.406)\end{array}$ & $\begin{array}{c}0.347 * * * \\
(0.084)\end{array}$ & $\begin{array}{l}-0.024 \\
(0.022)\end{array}$ \\
\hline Firm scale & $\begin{array}{c}6.266 * * * \\
(0.169)\end{array}$ & $\begin{array}{c}0.455^{* * *} \\
(0.020)\end{array}$ & $\begin{array}{c}0.044 * * * \\
(0.004)\end{array}$ \\
\hline Constant & $\begin{array}{c}-87.805^{* * * *} \\
(2.650)\end{array}$ & $\begin{array}{c}-4.429 * * * \\
(0.295)\end{array}$ & $\begin{array}{c}-0.361^{* * *} \\
(0.056)\end{array}$ \\
\hline Adj. $R^{2}$ & 0.300 & 0.111 & 0.035 \\
\hline Coefficient estimates & OLS & OLS & OLS \\
\hline Standard errors & White $^{2}$ & White & White \\
\hline
\end{tabular}

We explore whether the shareholding of institutional investors would be affected by industry category change, including changing once and more than once. The results are shown in Table 4 for the shareholding changes of foreign institutions, domestic institutions, and security dealers in Equations (2a) - (2c), respectively. Besides, we employ financial statement variables, including net profit ratio, asset turnover ratio, and debt ratio, board structure variables, including directors' shareholding ratio, managers' shareholding ratio, directors' pledge ratio, CEO duality dummy, and board size, and others, including electronic dummy and firm scale, as the controlling variables. The tstatistics are based on the standard errors that are adjusted by heteroscedasticity (White,

2 The standard errors are adjusted by heteroscedasticity proposed by White, 1980. 
1980) in Columns (2a) - (2c). Statistical significance values at the $10 \%$, $5 \%$, and $1 \%$ levels are denoted by *,**, and ***, respectively.

Table 4 Results for Multiple Regression Models in Terms of the industry Category Change

\begin{tabular}{|c|c|c|c|}
\hline \multicolumn{4}{|c|}{ Dependent variable : Shareholding of institutional investors } \\
\hline \multirow[b]{2}{*}{ Independent variable } & $(2 \mathrm{a})$ & $(2 \mathrm{~b})$ & $(2 c)$ \\
\hline & $\begin{array}{l}\text { Shareholding change } \\
\text { of foreign institutions }\end{array}$ & $\begin{array}{l}\text { Shareholding change } \\
\text { of domestic institutions }\end{array}$ & $\begin{array}{l}\text { Shareholding change } \\
\text { of security dealers }\end{array}$ \\
\hline \multirow{2}{*}{$\begin{array}{l}\text { Industry category change once } \\
\text { dummy }\end{array}$} & $-5.408 * * *$ & -0.032 & 0.013 \\
\hline & $(0.576)$ & $(0.081)$ & $(0.024)$ \\
\hline \multirow{2}{*}{$\begin{array}{l}\text { Industry category change more } \\
\text { than once dummy }\end{array}$} & 0.950 & $-0.299 * * *$ & $-0.036^{*}$ \\
\hline & $(0.588)$ & $(0.103)$ & $(0.019)$ \\
\hline \multirow[t]{2}{*}{ Net profit ratio } & $4.9 \mathrm{e}-4$ & $2.2 \mathrm{e}-4$ & $7 e-5$ \\
\hline & $(4.8 \mathrm{e}-4)$ & $(1.5 \mathrm{e}-4)$ & $(6 e-5)$ \\
\hline \multirow[t]{2}{*}{ Assets turnover ratio } & $2.117^{* * *}$ & $0.229 * * *$ & -0.007 \\
\hline & $(0.300)$ & $(0.042)$ & $(0.010)$ \\
\hline \multirow[t]{2}{*}{ Debt ratio } & $-0.023 * *$ & $-0.010^{* * *}$ & $-0.001 *$ \\
\hline & $(0.011)$ & $(0.001)$ & $(0.001)$ \\
\hline \multirow[t]{2}{*}{ Directors' shareholding ratio } & $-0.039 * *$ & $-0.011 * * *$ & $-0.002 * * *$ \\
\hline & $(0.019)$ & $(0.002)$ & $(0.001)$ \\
\hline \multirow[t]{2}{*}{ Managers' shareholding ratio } & -0.009 & -0.009 & $-0.003^{*}$ \\
\hline & $(0.077)$ & $(0.008)$ & $(0.002)$ \\
\hline \multirow[t]{2}{*}{ Directors' pledge ratio } & $-0.028 * * *$ & $-0.003^{* *}$ & $0.002 * *$ \\
\hline & $(0.009)$ & $(0.002)$ & $(0.001)$ \\
\hline \multirow[t]{2}{*}{ CEO duality dummy } & $1.786 * * *$ & $-0.148 * *$ & $-3 e-4$ \\
\hline & $(0.427)$ & $(0.071)$ & $(0.015)$ \\
\hline \multirow[t]{2}{*}{ Board size } & $-0.323 * * *$ & $-0.078 * * *$ & $-0.010 * * *$ \\
\hline & $(0.076)$ & $(0.011)$ & $(0.002)$ \\
\hline \multirow[t]{2}{*}{ Electronic dummy } & $4.464^{* * *}$ & $0.379 * * *$ & -0.031 \\
\hline & $(0.578)$ & $(0.083)$ & $(0.022)$ \\
\hline \multirow[t]{2}{*}{ Firm scale } & $6.260 * * *$ & $0.456 * * *$ & $0.043 * * *$ \\
\hline & $(0.168)$ & $(0.020)$ & $(0.004)$ \\
\hline \multirow[t]{2}{*}{ Constant } & $-85.942 * * *$ & $-4.473^{* * *}$ & $-0.330 * * *$ \\
\hline & $(2.626)$ & $(0.295)$ & $(0.056)$ \\
\hline Adj. $\mathrm{R}^{2}$ & 0.313 & 0.110 & 0.028 \\
\hline Coefficient estimates & OLS & OLS & OLS \\
\hline Standard errors & White & White & White \\
\hline
\end{tabular}

We reveal that the corporate name change once the dummy has a positive impact on the shareholding change of security dealers, indicating that corporate name change might increase the shareholding of security dealers. We infer that these firms might search for change by way of changing their firm names, which might appeal to some institutional investors such as security dealers to increase their shareholdings. However, the dummy variable of corporate name change more than once is negatively related to 
institutional investors, including foreign institutions, domestic institutions, and security dealers. We speculate that corporate name change twice or more might be the result of poor firm performance, which likely causes the decrease of the institutional investors' shareholding for this firm.

As for the results for industry category change, we find that industry category change once dummy is negatively related to the shareholding change of foreign institutions. Besides, industry category change more than once dummy has a negative effect onrms the shareholding changes of domestic institutions and security dealers. The results show that the firm changing industry category once or more than once might not have a positive signal for institutional investors, indicating that changing industry category might be recognized as not a real but a nominal change. Consequently, institutional investors might be decreasing instead of increasing their shareholdings for these firms.

As mentioned in the descriptive statistics section, some firms listed on the TWSE have higher debt ratios, lower directors' shareholding ratios, and higher directors pledge ratios. We then suspect that corporate governance and financial issues might exist in the firms. Therefore, we apply the variables in terms of board structure, financial statement, and others as the controlling variables for our models, which might enhance the revealed results and disclose the relationships among the board structure, the financial performance, as well as the shareholdings of institutional investors.

Concerning financial statement variables, the net profit ratio and the assets turnover ratio are all positively related to the shareholding change of institutional investors, implying that institutional investors prefer to increase the shareholding for the firms with higher net profit ratios and assets turnover ratios. However, the debt ratio is negatively related to the shareholding change of institutional investors. We argue that the firms with high debt ratios might increase interest expense and even surge financial risks, which might result in the decrease rather than the increase of the institutional investors' shareholdings for these firms.

As for board structure variables, Table 3 and Table 4 reveal that directors' shareholding ratios are negatively related to the shareholding change of institutional investors. The result might indicate that the firms with high directors' shareholding ratios might be controlled even intervened by the directors instead of the professional managers, which might result in that institutional investors may not prefer to increase the shareholdings of these firms. Besides, board size and directors' pledge ratio also have negative relationships with the shareholding change of institutional investors. In fact, the firms with large board size and higher directors pledge ratio might not be regarded as the well-functioned board structures, which might not enhance the shareholding of institutional investors consequently. 
As for other controlling variables, the electronic dummy and the firm scale have positive effects on the shareholding changes of foreign institutions as well as domestic institutions. We argue that institutional investors seem to prefer holding electronic firms, which might result from that several firms with the highly international competition are electronic firms with large firm scales.

\section{Petersen Regression Models}

Due to the defects of multiple regression models proposed, we employ the model proposed by Petersen for grasping the relative accuracy after taking the structure of the data into account, which would be beneficial for the robustness of our empirical results. We then present the results employed by Petersen models in Table 5 and Table 6 .

We explore whether the shareholding of institutional investors would be affected by the corporate name change, including changing once and more than once, and the results are shown in Table 5 for the shareholding changes of foreign institutions, domestic institutions, and security dealers in Equations (3a) - (3c), respectively. In addition, we employ financial statement variables, including net profit ratio, asset turnover ratio, and debt ratio, board structure variables, including directors' shareholding ratio, managers' shareholding ratio, directors' pledge ratio, CEO duality dummy, and board size, and others, including electronic dummy and firm scale, as the controlling variables. The t-statistics are based on the standard errors that are adjusted by the two-way clusters existed in firm and year (Petersen, 2009) in Columns (3a) (3c). Statistical significance values at the $10 \%, 5 \%$, and $1 \%$ levels are denoted by *, ${ }^{* *}$, and ${ }^{* * *}$, respectively. 
Table 5 Results for Petersen Models in Terms of the corporate name change

\begin{tabular}{|c|c|c|c|}
\hline \multicolumn{4}{|c|}{ Dependent variable : Shareholding of institutional investors } \\
\hline \multirow[b]{2}{*}{ Independent variable } & $(3 a)$ & $(3 \mathrm{~b})$ & $(3 c)$ \\
\hline & $\begin{array}{l}\text { Shareholding change } \\
\text { of foreign institutions }\end{array}$ & $\begin{array}{l}\text { Shareholding change } \\
\text { of domestic institutions }\end{array}$ & $\begin{array}{l}\text { Shareholding change } \\
\text { of security dealers }\end{array}$ \\
\hline $\begin{array}{l}\text { Corporate name change once } \\
\text { dummy }\end{array}$ & $\begin{array}{l}-0.488 \\
(1.127)\end{array}$ & $\begin{array}{l}-0.101 \\
(0.107)\end{array}$ & $\begin{array}{l}0.110^{*} \\
(0.058)\end{array}$ \\
\hline \multirow{2}{*}{$\begin{array}{l}\text { Corporate name change more } \\
\text { than once dummy }\end{array}$} & -1.978 & -0.198 & $-0.156^{* *}$ \\
\hline & $(1.815)$ & $(0.178)$ & $(0.065)$ \\
\hline \multirow[t]{2}{*}{ Net profit ratio } & $5.4 \mathrm{e}-4^{* *}$ & $2.2 \mathrm{e}-4$ & $7 e-5$ \\
\hline & $(2.4 \mathrm{e}-1)$ & $(1.3 \mathrm{e}-4)$ & $(9 e-5)$ \\
\hline \multirow[t]{2}{*}{ Assets turnover ratio } & $1.750 * * *$ & $0.243 * * *$ & -0.004 \\
\hline & $(0.634)$ & $(0.066)$ & $(0.018)$ \\
\hline \multirow[t]{2}{*}{ Debt ratio } & -0.014 & $-0.009 * * *$ & -0.001 \\
\hline & $(0.023)$ & $(2.3 e-3)$ & $(0.001)$ \\
\hline Directors' shareholding ratio & $\begin{array}{l}-0.029 \\
(0.035)\end{array}$ & $\begin{array}{c}-0.010 * * * \\
(0.003)\end{array}$ & $\begin{array}{l}-0.002 \\
(0.001)\end{array}$ \\
\hline Managers’ shareholding ratio & $\begin{array}{c}0.058 \\
(0.137)\end{array}$ & $\begin{array}{c}-0.011 * * \\
(0.011)\end{array}$ & $\begin{array}{l}-0.003 \\
(0.003)\end{array}$ \\
\hline \multirow[t]{2}{*}{ Directors’ pledge ratio } & $-0.038 * *$ & $-0.002 * * *$ & 0.002 \\
\hline & $(0.019)$ & $(0.002)$ & $(0.001)$ \\
\hline \multirow[t]{2}{*}{ CEO duality dummy } & $1.653^{*}$ & -0.166 & -0.001 \\
\hline & $(0.976)$ & $(0.118)$ & $(0.030)$ \\
\hline \multirow[t]{2}{*}{ Board size } & -0.249 & $-0.085^{* * *}$ & $-0.010 * *$ \\
\hline & $(0.152)$ & $(0.021)$ & $(0.004)$ \\
\hline \multirow[t]{2}{*}{ Electronic dummy } & 1.092 & $0.318 * *$ & -0.022 \\
\hline & $(0.811)$ & $(0.139)$ & $(0.028)$ \\
\hline \multirow[t]{2}{*}{ Firm scale } & $6.165^{* * *}$ & $0.466 * * *$ & $0.046 * * *$ \\
\hline & $(0.418)$ & $(0.057)$ & $(0.010)$ \\
\hline \multirow[t]{2}{*}{ Constant } & $-83.309 * * *$ & $-5.307 * * *$ & $-0.429 * * *$ \\
\hline & $(5.867)$ & $(0.703)$ & $(0.132)$ \\
\hline$\overline{\text { Adj. } R^{2}}$ & 0.284 & 0.090 & 0.027 \\
\hline Coefficient estimates & OLS & OLS & OLS \\
\hline Standard errors & CL-F\&Y ${ }^{3}$ & CL-F\&Y & CL-F\&Y \\
\hline
\end{tabular}

We explore whether the shareholding of institutional investors would be affected by industry category change, including changing once and more than once, and the results are shown in Table 6 for the shareholding changes of foreign institutions, domestic institutions, and security dealers in Equations (4a) - (4c), respectively. In addition, we employ financial statement variables, including net profit ratio, asset turnover ratio, and debt ratio, board structure variables, including directors' shareholding ratio, managers' shareholding ratio, directors' pledge ratio, CEO duality dummy, and board size, and others, including electronic dummy and firm scale, as the controlling variables. The t-statistics are based on the standard errors that are adjusted by the two-way clusters existed in firm and year (Petersen, 2009) in Columns (4a) -

${ }^{3}$ The standard errors are adjusted by the two-way clusters existed in firm and year proposed by Petersen, 2009. 
(4c). Statistical significance values at the $10 \%, 5 \%$, and $1 \%$ levels are denoted by *,**, and $* * *$, respectively.

Table 6 Results for Petersen models in terms of the industry category change

Dependent variable : Shareholding of institutional investors

\begin{tabular}{|c|c|c|c|}
\hline Independent variable & $\begin{array}{l}\text { ( } 4 \mathrm{a}) \\
\text { Shareholding change } \\
\text { of foreign institutions }\end{array}$ & $\begin{array}{l}\text { (4b) } \\
\text { Shareholding change } \\
\text { of domestic institutions }\end{array}$ & $\begin{array}{l}(4 \mathrm{c}) \\
\text { Shareholding change } \\
\text { of security dealers }\end{array}$ \\
\hline Industry category change & $-5.686 * * *$ & 0.027 & 0.012 \\
\hline once dummy & ( 1.503$)$ & $(0.124)$ & $(0.052)$ \\
\hline Industry category change & 0.941 & $-0.298 *$ & -0.036 \\
\hline more than once dummy & $(1.367)$ & $(0.176)$ & $(0.036)$ \\
\hline Net profit ratio & $\begin{array}{l}3.5 e-4 \\
(3 e-4)\end{array}$ & $\begin{array}{c}2.3 e-4^{*} \\
(1.3 e-4)\end{array}$ & $\begin{array}{c}7 e-5 \\
(9 e-5)\end{array}$ \\
\hline Assets turnover ratio & $\begin{array}{c}1.928 * * * \\
(0.610)\end{array}$ & $\begin{array}{c}0.248 * * * \\
(0.065)\end{array}$ & $\begin{array}{c}-0.010 \\
(0.021)\end{array}$ \\
\hline Debt ratio & $\begin{array}{c}-0.022 \\
(0.023)\end{array}$ & $\begin{array}{c}-0.010^{* * * *} \\
(0.002)\end{array}$ & $\begin{array}{c}-0.001 \\
(0.001)\end{array}$ \\
\hline Directors' shareholding ratio & $\begin{array}{c}-0.042 \\
(0.034)\end{array}$ & $\begin{array}{c}-0.010^{* * * *} \\
(0.003)\end{array}$ & $\begin{array}{c}-0.002 \\
(0.001)\end{array}$ \\
\hline Managers' shareholding ratio & $\begin{array}{c}0.005 \\
(0.135)\end{array}$ & $\begin{array}{c}-0.011 \\
(0.011)\end{array}$ & $\begin{array}{c}-0.003 \\
(0.003)\end{array}$ \\
\hline Directors' pledge ratio & $\begin{array}{l}-0.034^{*} \\
(0.018)\end{array}$ & $\begin{array}{c}-0.002 \\
(0.002)\end{array}$ & $\begin{array}{c}0.002 \\
(0.001)\end{array}$ \\
\hline CEO duality dummy & $\begin{array}{c}1.818^{*} \\
(1.015)\end{array}$ & $\begin{array}{c}-0.154 \\
(0.119)\end{array}$ & $\begin{array}{c}0.001 \\
(0.030)\end{array}$ \\
\hline Board size & $\begin{array}{l}-0.274^{*} \\
(0.153)\end{array}$ & $\begin{array}{c}-0.084 * * * \\
(0.021)\end{array}$ & $\begin{array}{c}-0.011 * * * \\
(0.004)\end{array}$ \\
\hline Electronic dummy & $\begin{array}{c}4.701^{* * * *} \\
(1.336)\end{array}$ & $\begin{array}{l}0.329 * * \\
(0.150)\end{array}$ & $\begin{array}{c}-0.029 \\
(0.047)\end{array}$ \\
\hline Firm scale & $\begin{array}{c}6.162 * * * \\
(0.420)\end{array}$ & $\begin{array}{c}0.466 * * * \\
(0.057)\end{array}$ & $\begin{array}{c}0.046 * * * \\
(0.010)\end{array}$ \\
\hline Constant & $\begin{array}{c}-81.620^{* * * *} \\
(5.787) \\
\end{array}$ & $\begin{array}{c}-5.339 * * * \\
(0.713) \\
\end{array}$ & $\begin{array}{c}-0.399 * * * \\
(0.133) \\
\end{array}$ \\
\hline Adj. $R^{2}$ & 0.299 & 0.0908 & 0.021 \\
\hline Coefficient estimates & OLS & OLS & OLS \\
\hline Standard errors & CL-F\&Y & CL-F\&Y & CL-F\&Y \\
\hline
\end{tabular}

Table 5 and Table 6 reveal almost the same results as Table 3 and Table 4 . The dummy variable of corporate name change once has a positive effect on the shareholding change of security dealers, while the dummy variable of corporate name change more than once is negatively related to institutional investors. We argue that a firm changes its name probably to seek survival and to expect a brand new start due to the poor performance in the past, which is somewhat acceptable for institutional investors. However, a firm changes its name twice or even more might not have a better impression for the firm, which may result in the decrease of institutional investors' 
shareholdings due to the concern of risk.

As for the results in terms of industry category change, the dummy of industry category change once has a significantly negative impact on the shareholding change of foreign institutions, and industry category change more than once dummy negatively influences the shareholding changes of domestic institutions and security dealers. We infer that firms change their industry categories might stem from pursuing a higher $\mathrm{P} / \mathrm{E}$ ratio in other industry categories. However, foreign institutions might consider that the industry category change would not change the essence of these firms; besides, institutional investors might regard these firms are speculative. Therefore, foreign institutions decrease their shareholdings for these firms in response.

As for the results shown for other controlling variables, the net profit ratio, the asset turnover ratio, and the firm scale are positively related to shareholding changes of foreign institutions and domestic institutions. These findings represent that foreign institutions and domestic institutions prefer to hold the shares of the firms with a high turnover ratio, implying that the firm with better asset management would appeal to institutional investors to increases their shareholdings.

In addition, institutional investors prefer to hold large-scale firms due to the concern of liquidity, which is revealed in this study as well. However, the large-scale firms might not have a higher director shareholding ratio. Besides, the tradeoff between director shareholding ratio and institutional shareholding ratio might result in the decline of directors' shareholding for large-scale firms.

\section{CONCLUSION}

Enterprises argue that corporate name might be related to the firm performance, and even play an important role in future prospects of enterprises because of the myth of cultural factors, especially for the Asian companies. Due to this myth, we are interested in the concern mentioned above, and conduct this study to explore whether changing the corporate name would impact the shareholdings of intuitional investors.

In addition, some firms might switch the original industry category to another due to the expectation of a higher P/E ratio compared to the original industry category. However, whether the industry category changed would attract institutional investors to increase their shareholding would be another issue to be discussed in this study, which seems rarely explored and even unexplored in the relevant studies after surveying the relevant literature shown in the second section.

By employing the firms listed on the TWSE as our samples, we explore whether the firm either changing the corporate name or switching industry category would affect the shareholding of institutional investors after taking into account the board structure, the financial performance, and others controlling variables. In addition, the 
shareholding of institutional investors, including foreign institutions, domestic institutions, and security dealers, are examined respectively, and then we reveal some remarkable findings as follows.

First, we find that institutional investors would not prefer to increase the shareholding for the firms changing their names more than once. We infer that institutional investors might suspect these firms without superior firm performance and even with difficulty in operating business, which results in the shareholding of institutional investors declined. Second, institutional investors might not prefer to hold the shares of the firms with industry categories changed once and even more since institutional investors might suspect that these firms might have corporate governance and even financial issues. Third, we identify that the debt ratio and the board size are negatively related to the shareholding change of institutional investors, implying that the firms with large board size and higher debt ratio might not have better corporate governance.

We argue that this study might contribute to the existing literature in the following aspects. First, we might be the pioneer to explore whether the shareholding change of institutional investors would be affected by either the corporate name change or the industry categories change since these two elements are seldom explored or even unexplored in the relevant studies. Second, we examine the shareholdings of diverse institutional investors, including foreign institutions, domestic institutions, and security dealers, which would be beneficial for realizing the shareholding changes of various institutional investors in response to the corporate name or industry category changes. Third, to our best understanding, our findings seem rarely reported in the previous studies and are valuable for investors to make investment strategies. Consulting the investment strategies made by institutional investors, individual investors might improve the probability of benefits obtained from the investment.

This study provides two valuable implications. First, individual investors should take into account the strategies made by institutional investors since, as the major participants in stock markets, institutional investors seem to be regarded as the informed traders. Thus, we argue that individual investors might follow the steps of institutional investors if firm names or industry categories changed might not be regarded as positive signals by institutional investors. Second, we claim that the firm with superior performance rather than the corporate name or industry category changed would appeal to institutional investors to increase their shareholding. As a result, enterprises indeed should make their efforts to improve their firm performances.

\section{REFERENCES}


Abed, S., Al-Attar, A., \& Suwaidan, M. (2012). Corporate governance and earnings management: Jordanian evidence. International Business Research, 5(1), 216225. https://doi.org/10.5539/ibr.v5n1p216

Aggarwal, R., Erel, I., Ferreira, M., \& Matos, P. (2011). Does governance travel around the world? Evidence from institutional investors. Journal of Financial Economics, 100(1), 154-181. https://doi.org/10.2139/ssrn.1361143

Agnihotri, A., \& Bhattacharya, S. (2017). Corporate name change and the market valuation of firms: Evidence from an emerging market. International Journal of the Economics of Business, 24(1), 73-90. https://doi.org/10.1080/13571516.2016.1253186

Ashforth, B. E., \& Gibbs, B. W. (1990). The double-edge of organizational legitimation. Organization Science, 1(2), 177-194. https://doi.org/10.1287/orsc.1.2.177

Bajo, E., Barbi, M., Bigelli, M., \& Hillier, D. (2013). The role of institutional investors in public-to-private transactions. Journal of Banking \& Finance, 37(11), 43274336. https://doi.org/10.2139/ssrn.2221420

Barton, J., \& Simko, P. J. (2002). The balance sheet as an earnings management constraint. The Accounting Review, 77(s-1), 1-27. https://doi.org/10.2139/ssrn.320641

Bena, J., Ferreira, M. A., Matos, P., \& Pires, P. (2017). Are foreign investors locusts? The long-term effects of foreign institutional ownership. Journal of Financial Economics, 126(1), 122-146. https://doi.org/10.1016/j.jfineco.2017.07.005

Boddewyn, J. (1967). The names of US industrial corporations: A study in change. Names, 15(1), 39-52. https://doi.org/10.1179/nam.1967.15.1.39

Borokhovich, K. A., Brunarski, K. R., Crutchley, C. E., \& Simkins, B. J. (2004). Board composition and corporate use of interest rate derivatives. Journal of Financial Research, 27(2), 199-216. https://doi.org/10.1111/j.1475-6803.2004.t01-1-00079.x

Bosch, J. C., \& Hirschey, M. (1989). The valuation effects of corporate name changes. Financial Management, 18(4), 64-73. https://doi.org/10.2307/3665798

Brick, I. E., \& Chidambaran, N. K. (2010). Board meetings, committee structure, and firm value. Journal of Corporate Finance, 16(4), 533-553. https://doi.org/10.1016/j.jcorpfin.2010.06.003

Bushee, B. J. (1998). The influence of institutional investors on myopic R\&D investment behavior. The Accounting Review, 73(3), 305-333.

Carson, J. M., Cole, C. R., \& Fier, S. G. (2016). Name changes and future growth: 
Evidence from the life insurance industry. Journal of Insurance Issues, 1-37.

Chang, Y. Y., \& Young, M. (2016). Brand firm performance and tough economic times. International Review of Finance, 16(3), pp. 357-391.

https://doi.org/10.1111/irfi.12081

Chen, G., Luo, S., Tang, Y., \& Tong, J. Y. (2015). Passing probation: Earnings management by interim CEOs and its effect on their promotion prospects. Academy of Management Journal, 58(5), 1389-1418.

https://doi.org/10.5465/amj.2013.0351

Chung, K. H., \& Zhang, H. (2011). Corporate governance and institutional ownership. Journal of Financial and Quantitative Analysis, 46(1), 247-273.

Cooper, M. J., Dimitrov, O., \& Rau, P. R. (2001). A rose.com by any other name. The Journal of Finance, 56(6), 2371-2388.

Cooper, M. J., Khorana, A., Osobov, I., Patel, A., \& Rau, P. R. (2005). Managerial actions in response to a market downturn: Valuation effects of name changes in the dot. com decline. Journal of Corporate Finance, 11(1), 319-335. https://doi.org/10.2139/ssrn.375820

Dahlquist, M., \& Robertsson, G. (2001). Direct foreign ownership, institutional investors, and firm characteristics. Journal of Financial Economics, 59(3), 413440. https://doi.org/10.1016/s0304-405x(00)00092-1

Daly, A., \& Moloney, D. (2004). Managing corporate rebranding. Irish Marketing Review, 17(1/2), 30-36.

Das, P. (2014). The role of corporate governance in foreign investments. Applied Financial Economics, 24(3), 187-201. https://doi.org/10.1080/09603107.2013.870650

Davis, E. P. (2002). Institutional investors, corporate governance and the performance of the corporate sector. Economic Systems, 26(3), 203-229. https://doi.org/10.1016/s0939-3625(02)00044-4

Delattre, E. (2002). Business name changes: The French experience. Journal of Small Business Management, 40(4), 360-367. https://doi.org/10.1111/1540-627x.00063

Feng, X., Zhou, M., \& Chan, K. C. (2014). Smart money or dumb money? A study on the selection ability of mutual fund investors in China. The North American Journal of Economics and Finance, 30, 154-170. https://doi.org/10.1016/j.najef.2014.09.004

Ferreira, M. A., \& Matos, P. (2008). The colors of investors' money: The role of institutional investors around the world. Journal of Financial Economics, 88(3), 499-533. https://doi.org/10.1016/j.jfineco.2007.07.003 
Ferreira, M. A., Massa, M., \& Matos, P. (2009). Shareholders at the gate? Institutional investors and cross-border mergers and acquisitions. The Review of Financial Studies, 23(2), 601-644. https://doi.org/10.1093/rfs/hhp070

Filatotchev, I., Lien, Y. C., \& Piesse, J. (2005). Corporate governance and performance in publicly listed, family-controlled firms: Evidence from Taiwan. Asia Pacific Journal of Management, 22(3), 257-283. https://doi.org/10.1007/s10490-0053569-2

Foster, F. D., \& Warren, G. J. (2016). Interviews with institutional investors: The how and why of active investing. Journal of Behavioral Finance, 17(1), 60-84. https://doi.org/10.1080/15427560.2015.1095754

Garg, A., \& Chawla, K. K. (2015). A study of trend analysis and relationship between foreign institutional investors (FIIs) \& domestic institutional investors (DIIs). International Multi Track Conference on Sciences, Engineering \& Technical Innovations, 321-325. https://doi.org/10.2139/ssrn.2623465

Gillan, S., \& Starks, L. T. (2003). Corporate governance, corporate ownership, and the role of institutional investors: A global perspective. Weinberg Center for Corporate Governance Working Paper No. 2003-01.

https://doi.org/10.2139/ssrn.439500

Glynn, M. A., \& Abzug, R. (2002). Institutionalizing identity: Symbolic isomorphism and organizational names. Academy of Management Journal, 45(1), 267-280. https://doi.org/10.5465/3069296

Green, T. C., \& Jame, R. (2013). Company name fluency, investor recognition, and firm value. Journal of Financial Economics, 109(3), 813-834. https://doi.org/10.1016/j.jfineco.2013.04.007

Grinblatt, M., \& Keloharju, M. (2000). The investment behavior and performance of various investor types: A study of Finland's unique data set. Journal of Financial Economics, 55(1), 43-67. https://doi.org/10.1016/s0304-405x(99)00044-6

Guha, S. (2018). Institutional investors and firm characteristics: New evidence from India.” Research in International Business and Finance, 46, 30-42. https://doi.org/10.1016/j.ribaf.2017.09.005

Harford, J., Mansi, S. A., \& Maxwell, W. F. (2008). Corporate governance and firm cash holdings in the US. Journal of Financial Economics, 87, 535-555. https://doi.org/10.1016/j.jfineco.2007.04.002

Horsky, D., \& Swyngedouw, P. (1987). Does it pay to change your company's name? A stock market perspective. Marketing Science, 6(4), 320-335.

https://doi.org/10.1287/mksc.6.4.320 
Howe, J. S. (1982). A rose by any other name? A note on corporate name changes. Financial Review, 17(4), 271-278. https://doi.org/10.1111/j.1540-6288.1982.tb00510.x

Hsu, M. F., \& Wang, K. (2014). The level and stability of institutional ownership and firm performance: Evidence from Taiwan. Emerging Markets Finance and Trade, 50(sup2), 159-173. https://doi.org/10.2753/ree1540-496x5002s211

Huang, R. D., \& Shiu, C. Y. (2009). Local effects of foreign ownership in an emerging financial market: Evidence from qualified foreign institutional investors in Taiwan. Financial Management, 38(3), 567-602. https://doi.org/10.1111/j.1755053x.2009.01048.x

Itzkowitz, J., \& Itzkowitz, J. (2017). Name-based behavioral biases: Are expert investors immune? Journal of Behavioral Finance, 18(2), 180-188. https://doi.org/10.1080/15427560.2017.1308940

Jacobides, M. G. (2005). Industry change through vertical disintegration: How and why markets emerged in mortgage banking. Academy of Management Journal, 48(3), 465-498. https://doi.org/10.5465/amj.2005.17407912

Josev, T., Chan, H., \& Faff, R. (2004). What's in a name? Evidence on corporate name changes from the Australian capital market. Pacific Accounting Review, 16(1), 5776. https://doi.org/10.1108/01140580410818469

Karbhari, Y., Muhamad Sori, Z., \& Mohamad, S. (2004). Shareholder wealth effects and corporate name change: Evidence from Malaysia. Corporate Ownership \& Control, 2(1), 38-49. https://doi.org/10.22495/cocv2i1p3

Karpoff, J. M., \& Rankine, G. (1994). In search of a signaling effect: The wealth effects of corporate name changes. Journal of Banking \& Finance, 18(6), 1027-1045. https://doi.org/10.1016/0378-4266(94)00058-1

Kashmiri, S., \& Mahajan, V. (2015). The name's the game: Does marketing impact the value of corporate name changes? Journal of Business Research, 68(2), 281-290. https://doi.org/10.1016/j.jbusres.2014.07.007

Kaur, M., \& Dhillon, S. S. (2010). Determinants of foreign institutional investors investment in India. Eurasian Journal of Business and Economics, 3(6), 57-70.

Khurana, I. K., \& Moser, W. J. (2013). Institutional shareholders' investment horizons and tax avoidance. The Journal of the American Taxation Association, 35(1), 111134. https://doi.org/10.2308/atax-50315

Ko, K., Kim, K., \& Cho, S. H. (2007). Characteristics and performance of institutional and foreign investors in Japanese and Korean stock markets. Journal of the Japanese and International Economies, 21(2), 195-213. 
https://doi.org/10.1016/j.jjie.2005.11.002

Kot, H. W. (2011). Corporate name changes: Price reactions and long-run performance. Pacific-Basin Finance Journal, 19(2), 230-244.

https://doi.org/10.1016/j.pacfin.2010.10.003

Lai, H. C., \& Wang, K. M. (2014). Relationship between the trading behavior of three institutional investors and Taiwan Stock Index futures returns. Economic Modelling, 41, 156-165. https://doi.org/10.1016/j.econmod.2014.05.007

Lee, P. M. (2001). What's in a name. com?: The effects of '. com'name changes on stock prices and trading activity. Strategic Management Journal, 22(8), 793-804. https://doi.org/10.1002/smj.177

Lemma, T. T., Negash, M., Mlilo, M., \& Lulseged, A. (2018). Institutional ownership, product market competition and earnings management: Some evidence from international data. Journal of Business Research, 90, 151-163.

https://doi.org/10.1016/j.jbusres.2018.04.035

Li, T., \& Zaiats, N. (2018). Corporate governance and firm value at dual class firms. Review of Financial Economics, 36(1), 47-71. https://doi.org/10.1016/j.rfe.2017.07.001

Lin, H. M., Yang, S. A., \& Chang, Y. (2016). The wealth effects of oil-related name changes on stock prices: Evidence from the US and Canadian stock markets. Journal of International Financial Markets, Institutions and Money, 40, 26-45. https://doi.org/10.1016/j.intfin.2015.07.003

Liu, N., Bredin, D., Wang, L., \& Yi, Z. (2014). Domestic and foreign institutional investors' behavior in China. The European Journal of Finance, 20(7-9), 728-751. https://doi.org/10.1080/1351847x.2012.671778

Luong, H., Moshirian, F., Nguyen, L., Tian, X., \& Zhang, B. (2017). How Do Foreign Institutional Investors Enhance Firm Innovation?. Journal of Financial and Quantitative Analysis, 52(4), 1449-1490. https://doi.org/10.1017/s0022109017000497

Mathuva, D. M., Muthuma, E. W., \& Kiweu, J. M. (2016). The impact of name change on the financial performance of savings and credit co-operatives in Kenya. Management Research Review, 39(10), 1265-1292. https://doi.org/10.1108/mrr-04-2015-0097

Min, B. S., \& Verhoeven P. (2013). Outsider board activity, ownership structure and firm value: Evidence from Korea. International Review of Finance, 13(2), 187214. https://doi.org/10.1111/irfi.12004

Morris, L. J., \& Reyes, M. G. (2011). Corporate name changes: The association between 
functional name characteristics and stock performance. Journal of Applied Business Research (JABR), 8(1), 110-117. https://doi.org/10.19030/jabr.v8i1.6190

Morris, T., Storey, J., Wilkinson, A., \& Cressey, P. (2001). Industry change and union mergers in British retail finance. British Journal of Industrial Relations, 39(2), 237-256. https://doi.org/10.1111/1467-8543.00198

Muzellec, L. (2006). What is in a name change? Re-joycing corporate names to create corporate brands. Corporate Reputation Review, 8(4), 305-316. https://doi.org/10.1057/palgrave.crr.1540257

Muzellec, L., \& Lambkin, M. (2006). Corporate rebranding: Destroying, transferring or creating brand equity?. European Journal of Marketing, 40(7/8), 803-824. https://doi.org/10.1108/03090560610670007

Ni, Y., Liao, Y., \& Huang, P. (2017). Foreign institutional investors, shareholding change, and corporate governance. Emerging Markets Finance and Trade, 53(4), 764-775. https://doi.org/10.1080/1540496x.2015.1105634

Olins, W. (1989). Corporate Identitiy. Boston: Harvard Business School Press.

Petersen, M. A. (2009). "Estimating standard errors in finance panel data sets: Comparing approaches”, The Review of Financial Studies, 22(1), 435-480. https://doi.org/10.1093/rfs/hhn053

Rani, N., \& Asija, A. (2017). Signaling power of corporate name change: A case of Indian firms. Global Journal of Flexible Systems Management, 18(3), 173-181. https://doi.org/10.1007/s40171-017-0155-7

Schmeltz, L., \& Kjeldsen, A. K. (2016). Naming as strategic communication: Understanding corporate name change through an integrative framework encompassing branding, identity and institutional theory. International Journal of Strategic Communication, 10(4), 309-331. https://doi.org/10.1080/1553118x.2016.1179194

Schuppli, M., \& Bohl, M. T. (2010). Do foreign institutional investors destabilize China's A-share markets? Journal of International Financial Markets, Institutions and Money, 20(1), 36-50. https://doi.org/10.1016/j.intfin.2009.10.004

Stepanyan, G. G. (2011). Foreign Institutional Investors. Available at SSRN: https://ssrn.com/abstract=1799390.

Tadelis, S. (1999). What's in a name? Reputation as a tradeable asset. American Economic Review, 89(3), 548-563. https://doi.org/10.1257/aer.89.3.548

Tadelis, S. (2003). Firm reputation with hidden information. Economic Theory, 21(23), 635-651.

Tai, V. W., Lai, Y. H., \& Lin, L. (2014). Local institutional shareholders and corporate 
hedging policies. The North American Journal of Economics and Finance, 28, 287-312. https://doi.org/10.1016/j.najef.2014.03.009

Upadhyay, A. D., Bhargava, R., Faircloth, S., \& Zeng, H. (2017). Inside directors, risk aversion and firm performance. Review of Financial Economics, 32, 64-74. https://doi.org/10.1016/j.rfe.2016.12.001

Watson, A., Dada, O. L., Grünhagen, M., \& Wollan, M. L. (2016). When do franchisors select entrepreneurial franchisees? An organizational identity perspective. Journal of Business Research, 69(12), 5934-5945.

https://doi.org/10.1016/j.jbusres.2016.05.006

Wu, Y. (2010). What's in a name? What leads a firm to change its name and what the new name foreshadows. Journal of Banking and Finance, 34(6), 1344-1359. https://doi.org/10.1016/j.jbankfin.2009.11.029

Yoon, S. S., \& Park, M. K. (2015). The effect of name changes on the earnings management in Korea. Academy of Accounting and Financial Studies Journal, 19(2), 191.

Zou, L., Tang, T., \& Li, X. (2016). A tale of two styles: Do qualified foreign institutional investors have an edge over domestic funds managers in China? SSRN Electronic Journal, Jan. https:// 10.2139/ssrn.2724349

Dr. Paoyu Huang (Corresponding author) is a Professor in Department of International Business, Soochow University, Taiwan. She received the Ph.D. degree in Department of Management Sciences, Tamkang University, Taiwan. Her research interests lie in issues relating to corporate governance, capital market, microstructure, and technical analysis.

Dr. Yensen Ni is a Professor in Department of Management Sciences, Tamkang University, Taiwan. He received the Ph.D. degree in Department of Economics, University of Illinois at Chicago. His research interests include corporate governance, capital market, and microstructure, and technical analysis.

Dr. Yirung Cheng is a Ph.D. of Department of Management Sciences at Tamkang University, his research interests include corporate governance, capital market, and technical analysis. 